\title{
KEPUASAN KONSUMEN TIDAK SELALU MEMBENTUK LOYALITAS
}

\author{
Yasintha Soelasih \\ Fakultas Ekonomi dan BisnisUniveristas Katolik Atma Jaya, Jakarta, Indonesia \\ sinthajkt@yahoo.com; yasintha.soelasih@atmajaya.ac.id
}

\begin{abstract}
Train users in Indonesia began to increase, it can be seen from the data of passengers as a whole increased from year to year. These improvements must be supported with the customer perceived value, because it will affect of rail users. Long distance train in Indonesia distinguished its kind, namely the executive, business and economics. In this study, it more emphasis on the train executives, especially in Java. Issues examined here is whether the customer perceived value have an influence on satisfaction and commitment resulting in loyalty. This affects the sustainability of a rail business, because the level of competition arise among existing transportation, whether by air, land or sea. Sampling was done by simple random sampling, the number of respondents was 323 . The instrument was tested with reliability and validity. The data used to answer the problem by using structural equation modeling with six hypotheses were tested. The results indicate that the hypothesis occurs between the customer perceived value influence consumer satisfaction and commitment. The effect between satisfaction and commitment to loyalty shows that satisfaction has no effect on loyalty, commitment while consumers have an influence on loyalty.
\end{abstract}

Keywords: customer perceived value, customer satisfaction, customer loyalty, executive train, service quality

\begin{abstract}
Abstrak: Pengguna kereta api di Indonesia mulai meningkat, terlihat dari data yang menunjukkan jumlah penumpang secara keseluruhan meningkat dari tahun ke tahun. Peningkatan ini harus didukung dengan nilai yang diterima konsumen semakin baik, karena akan mempengaruhi dari pengguna kereta api. Kereta api jarak jauh di Indonesia dibedakan jenisnya yaitu eksekutif, bisnis dan ekonomi. Pada penelitian ini lebih menekankan pada kereta api eksekutif terutama di Pulau Jawa. Permasalahan yang akan diteliti adalah apakah nilai yang diterima konsumen mempunyai pengaruh terhadap kepuasan dan komitmen sehingga menimbulkan loyalitas. Hal ini mempengaruhi keberlangsungan dari suatu usaha perkeretaapian, karena tingkat persaingan timbul diantara transportasi yang ada, baik udara, darat maupun laut. Pengambilan sampel dilakukan dengan acak sederhana, jumlah responden yang terambil 323. Untuk instrument yang digunakan diuji dengan reliabilitas dan validitas. Pengujian data untuk menjawab permasalahan yang ada menggunakan structural equation modelling dengan enam hipotesis yang diuji. Hasil hipotesis menunjukkan bahwa terjadi pengaruh antara nilai yang diterima konsumen dengan kepuasan dan komitmen. Untuk pengaruh antara kepuasan dan komitmen terhadap loyalitas menunjukkan bahwa kepuasan tidak mempunyai pengaruh terhadap loyalitas, sedangkan komitmen konsumen mempunyai pengaruh terhadap loyalitas.
\end{abstract}

Kata Kunci: konsumen, komitmen, pengguna, kepuasan. 


\section{PENDAHULUAN}

Indonesia suatu Negara kepulauan sehingga membutuhkan alat transportasi yang beranekaragam. Transportasi antar pulau dapat dilakukan dengan menggunakan udara maupun laut. Untuk transportasi didalam pulau menggunakan darat, laut dan udara. Hal ini menimbulkan perkembangan yang pesat pada transportasi darat, laut maupun udara. Untuk di Pulau Jawa dan Sumatera transportasi darat terdiri dari perkeretaapian maupun angkutan darat lainnya yang dapat berupa kendaraan umum maupun pribadi. Oleh karena itu perkembangan transportasi darat khususnya di Pulau Jawa terlihat sangat cepat untuk kondisi jalan yang semakin baik dengan adanya jalan tol yang akan menghubungkan kota dari ujung Barat Jawa sampai Ujung Timur Jawa. Begitu juga transportasi perkeretaapian dapat dilakukan dari Barat sampai Timur Pulau Jawa. Perkembangan perkeretaapian menimbulkan animo masyarakat terhadap moda ini semakin tinggi. Hal ini terlihat pada kenaikan penumpang kereta api. Bila dilihat data dari tahun 2011 - 2015 penumpang kereta api dan commuter mengalami peningkatan dari tahun ke tahun. Tabel 1 menunjukkan jumlah penumpang dari tahun $2011-2015$.

Tabel 1. Jumlah Penumpang Kereta Api dan Commuter (ribu)

\begin{tabular}{ll}
\hline Tahun & Penumpang \\
\hline 2011 & 199,337 \\
2012 & 202,179 \\
2013 & 216,010 \\
2014 & 277,508 \\
2015 & 325,945
\end{tabular}

Sumber: BPS

Tabel 1 menunjukkan kenaikan secara keseluruhan jumlah penumpang kereta api dan commuter yang ada di Indonesia. Kenaikan ini menunjukkan semakin banyaknya pengguna transportasi kereta api dan commuter. Tabel 2 menunjukkan jumlah penumpang di Pulau Jawa, Sumatera dan Commuter.

Tabel 2. Jumlah Penumpang Kereta Api dan Commuter (ribu)

\begin{tabular}{crrr}
\hline Tahun & Commuter & $\begin{array}{c}\text { Jawa non } \\
\text { Commuter }\end{array}$ & Sumatera non Commuter \\
\hline 2011 & 121,105 & 72,936 & 5,296 \\
2012 & 134,088 & 63,707 & 4,384 \\
2013 & 158,483 & 53,532 & 3,995 \\
2014 & 208,496 & 64,108 & 4,904 \\
2015 & 257,531 & 63,090 & 5,324 \\
\hline
\end{tabular}

Sumber: BPS

Terlihat di tabel 2 bahwa kenaikan yang terjadi pada pengguna commuter di Jakarta, Bekasi, Bogor dan Tangerang dibandingkan pengguna kereta api jarak jauh baik di Pulau Jawa maupun Sumatera. Untuk pengguna kereta api jarak jauh di Pulau Jawa terjadi penurunan pada tahun 2012 dan 2013, walaupun pada tahun 2014 terjadi kenaikan tetapi pada tahun 2015 terjadi penurunan kembali walaupun tidak terlalu besar. Untuk Pulau Sumatera terjadi penurunan pada tahun 2012 dan 2013 tetapi tahun 2014 dan 2015 
terjadi kenaikan. Oleh karena itu perlu pengkajian untuk meningkatkan jumlah penumpang setiap tahunnya. Hal ini disebabkan banyaknya pilihan bagi konsumen dalam menggunakan transportasi yang ada di Indonesia.

PT KAI membedakan jenis kelas yang ada untuk penumpang jarak jauh yaitu eksekutif, bisnis dan ekonomi. Perbedaan untuk kereta api jarak jauh pada fasilitas, harga dan kenyamanan untuk pengguna kereta api. Walaupun ada perbedaan tetapi untuk ketepatan keberangkatan semua jenis kereta api relatif sama.

Kereta api merupakan salah satu bentuk dari perusahaan jasa. Pada jasa konsumen semakin kritis didalam menggunakan pelayanan tersebut. Mereka membandingkan antara manfaat yang diterima dengan biaya yang dikeluarkan. Oleh karena itu ukuran kepuasan menjadi penting bagi konsumen (Soelasih, 2015). Hasil penelitian Pantouvakis (2008) menunjukkan bahwa kepuasan merupakan suatu variabel yang dipengaruhi oleh variabel yang lainnya, sehingga penelitian yang dilakukan menunjukkan bahwa suatu lingkungan fisik didalam transportasi akan menimbulkan kepuasan bagi konsumen. Penelitian Tung (2013) menunjukkan bahwa perceived quality mempunyai pengaruh positif langsung dan tidak langsung terhadap kepuasan konsumen dan perceived value mempunyai pengaruh positif terhadap kepuasan konsumen. Nilai yang diterima konsumen (customer perceived value) merupakan perbandingan antara kualitas produk dengan pengorbanan yang dilakukan oleh konsumen (Roig; Garcia; Tena; Monzonis; 2006) bila manfaat dari kualitas produk lebih tinggi dibandingkan pengorbanan maka menimbulkan kepuasan yang tinggi bagi konsumen sehingga secara sadar maupun tidak sadar menimbulkan pengalaman yang unik dalam penggunaan produk tersebut (Schwandt 2003; Vargo; Lusch 2008a). Hasil penelitian Deng, Lu, Wei, Zhang (2010) menyebutkan bahwa kepuasan konsumen menimbulkan loyalitas konsumen (customer loyalty). Kepuasan konsumen dibutuhkan oleh perusahaan tetapi tidak cukup untuk dapat memprediksi loyalitas konsumen (Kumar; Pozza; Ganesh., 2013). Walaupun banyak penelitian yang menghasilkan bahwa kepuasan mempunyai pengaruh terhadap loyalitas, tetapi penelitian Kumar et.al.,2013 menyatakan bahwa kepuasan tidak cukup untuk membentuk loyalitas. Loyalitas konsumen juga terjadi bila timbul komitmen bagi konsumen dalam menggunakan produk atau jasa yang sama (Kaur; Soch, 2013). Peningkatan kepuasan konsumen (customer satisfaction) menyebabkan loyalitas konsumen dengan nilai produk/jasa yang diterima mereka (Yang; Peterson, 2004).

Oleh karena itu penting dilakukan penelitian bagi penumpang kereta api. Apakah terjadi masalah pada nilai yang diterima konsumen (customer perceived value), komitmen konsumen (customer commitment) dan kepuasan konsumen (customer satisfaction) yang dirasakan oleh konsumen sehingga menyebabkan mereka menjadi tidak loyal terhadap kereta api eksekutif? Tujuan penelitian ini untuk melihat pengaruh nilai yang diterima konsumen terhadap komitmen, kepuasan dan loyalitas konsumen.

\section{KAJIAN TEORI}

Dalam kajian teori akan dibahas nilai yang diterima konsumen (customer perceived value), komitmen konsumen (customer commitment), kepuasan konsumen (customer satisfaction), dan loyalitas konsumen (customer loyalty).

Nilai yang diterima Konsumen (Customer perceived value). Produk dan jasa yang diberikan kepada konsumen untuk dikonsumsi mereka selalu mempunyai manfaat yang 
harus diperhatikan oleh perusahaan. Produk dan jasa yang mempunyai manfaat tersebut menyebabkan konsumen akan merasa puas atau tidak yang berakibat pada pembelian ulang oleh konsumen. Hal inilah yang menyebabkan perusahaan perlu memperhatikan manfaat yang akan diberikan dari suatu produk dan jasa yang dihasilkan supaya dapat bersaing dalam industri.

Nilai suatu produk atau jasa yang dirasakan oleh konsumen merupakan hasil evaluasi yang dilakukan dengan membandingkan antara manfaat dari suatu produk, jasa, atau relasi dengan biaya atau pengorbanan yang dikeluarkan (Roig; et.al., 2006). Nilai konsumen (customer value) merupakan perbandingan dari benefitsuatu produk atau jasa yang diterima dan biaya yang dikeluarkan oleh konsumen (Heskett; Jones; Loveman; Sasser; Schlesinger; 1994). Bila benefit bagi konsumen lebih tinggi dibandingkan dengan biaya yang dikeluarkan oleh konsumen maka akan membentuk nilai konsumen yang tinggi. Bila nilai yang diterima konsumen diberikan secara terus menerus maka akan menjadikan keunggulan kompetitif bagi perusahaan tersebut, oleh karena itu perlu perhatian bagi perusahaan untuk memberikan nilai yang tinggi kepada konsumen (Roig; et.al, 2006). Nilai yang diberikan kepada konsumen secara terus menerus dengan relasi atau hubungan yang terbentuk akan akan meningkatkan loyalitas bagi konsumen (McMullan; Gilmore, 2008).

Banyak penelitian yang menggunakan kategori dalam nilai konsumen. Antara lain penelitian Woodruff, 1997. Ada lima kategori dalam nilai konsumen yang ada pada produk yang didasarkan pada fungsional, sosial, emosional, epistemik dan conditional value (Woodruff, 1997). Menurut Woodruff (1997) dalam penelitiannya yang merujuk pada penelitian Burns (1993) ada empat macam value: product value, value in use, possession value dan overall value. Sedangkan dalam penelitian Sweeney dan Soutar, 2001, nilai yang diterima konsumen dibedakan menjadi empat yaitu emotional value, social value (enhancement of social seft-concept), functional value (price/value for money) dan functional value (performancelquality). Oleh karena itu penelitian ini merujuk pada dimensi yang digunakan oleh Sweeney dan Soutar.

Komitmen Konsumen (Customer commitment). Konsumen yang punya komitmen terhadap produk atau jasa yang dikonsumsi akan meningkatkan loyalitas (Kaur; et.al., 2013). Komitmen yang tinggi oleh konsumen menjadi tolok ukur tingkat loyalitas yang tinggi juga (Eakuru; Mat, 2008). Dasar terbentuknya komitmen bila nilai yang diidentifikasi dan diterima oleh konsumen tinggi sehingga mempunyai dampak positif terhadap loyalitas (Fullerton, 2003). Ada 2 bentuk komitmen yaitu affective commitment dan calculative, atau continuance commitment (Fullerton, 2003; Kaur et.al, 2013). Hasil penelitian mereka menunjukkan bahwa komitmen affective mempunyai pengaruh positif terhadap sikap loyalitas dibandingkan komitmen kalkulatif mempunyai pengaruh negative terhadap sikap loyalitas (Fullerton, 2011; Kaur et.al.,2013). Yang; Chen; Chein (2014) mendefinisikan afektif komitmen sebagai hubungan yang saling menguntungkan antara penyedia dan penerima layanan. Untuk meningkatkan komitmen konsumen maka perusahaan harus memberikan perhatian yang lebih dibandingkan dengan pesaingnya (Al-Hawari, 2011).

Kepuasan Konsumen (Customer satisfaction). Fokus pada kepuasan konsumen yang dilakukan oleh perusahaan merupakan program pemasaran yang efektif (Yang et.al., 2004). Kualitas pelayanan yang diterima dan nilai yang diberikan kepada konsumen baik 
produk maupun jasa menimbulkan kepuasan konsumen ((Lim; Widdows; Park, 2006). Peningkatan kepuasan bagi konsumen secara terus menerus maka akan meningkatkan loyalitas (Yang et.al., 2004, Deng; Lu; Wei; Zhang,2010). Bila kepuasan terjadi maka menimbulkan pembelian kembali oleh konsumen (Soelasih, 2015) yang akhirnya menyebabkan loyalitas. Penelitian Ryu, Lee dan Kim (2012) melihat pengaruh dari kualitas layanan, kualitas makanan dan kualitas lingkungan fisik yang membentuk nilai yang diterima konsumen dan pengaruhnya terhadap kepuasan konsumen dan berdampak terhadap pembelian kembali. Hasil penelitian Ryu et.,al (2012), menyatakan bahwa kepuasan konsumen terjadi pada nilai yang diterima oleh konsumen tersebut. Kepuasan yang muncul pada diri konsumen menimbulkan loyalitas sehingga menguntungkan bagi perusahaan (Forgas-Coll; Palau-Saumell; Sanchez-Garcia; Fandos-Roig, 2013; Pantouvakis; Lymperopoulos, 2008).

Customer perceived value, customer commitment, customer satisfaction dan customer loyalty. Perusahaan-perusahaan yang menghasilkan produk atau jasa yang sama penting untuk memperhatikan nilai konsumen (Lapierre, 2000), nilai konsumen yang diciptakan dalam wujud produk atau jasa dapat menjadikan keunggulan kompetitif bagi perusahaan (Lichtenthal; Wilson; Long 1997). Menurut Bolton dan Lemon (1999), pada konsep ekuitas, konsumen akan memperhatikan kesesuaian dari pengorbanan yang dilakukan dalam pertukaran tersebut. Pengorbanan yang dilakukan oleh konsumen baik secara moneter maupun non moneter (Bolton et.al., 1999) akan diperhitungkan oleh konsumen. Oleh karena itu nilai yang diterima konsumen akan mempengaruhi kepuasan konsumen (customer satisfaction). Nilai yang diterima konsumen menjadi dasar dalam pembelian kembali oleh konsumen (Chang dan Wildt, 1994). Dalam penelitian Deng et.al., (2010) menunjukkan bahwa nilai yang diterima konsumen mempengaruhi tingkat kepuasan dan loyalitas konsumen. Nilai yang diterima konsumen dengan dimensi yang digunakan yaitu economic value, emotional value dan social value yang diuji bersama-sama menunjukkan hasil bahwa dimensi tersebut mempunyai pengaruh terhadap kepuasan konsumen (Shoki; Fen; Zakuan; Ishak; Ismail, 2012). Nilai yang diterima konsumen merupakan prediksi yang baik didalam membentuk kepuasan konsumen (Raji; Zainal, 2016).

H1 : Terjadi pengaruh antara nilai yang diterima konsumen (customer perceived value) terhadap kepuasan konsumen (customer satisfaction)

Nilai yang diterima konsumen dengan ukuran social value, emotional value dan conditional value mempunyai pengaruh terhadap komitmen (Mosavi; Ghaedi, 2012).

$\mathrm{H} 2$ : Terjadi pengaruh antara nilai yang diterima konsumen (customer perceived value) terhadap komitmen konsumen (customer commitment)

Parasuraman dan Grewal (2000) mengatakan bahwa perusahaan dapat memberikan superior customer value dengan excellent service dan quality product. Hal ini terjadi karena semua perusahaan yang sejenis akan menciptakan produk atau jasa yang mempunyai nilai bagi penggunanya. Jika semua perusahaan menggunakan konsep yang sama dengan memberikan nilai bagi konsumennya maka perusahaan yang dapat memberikan nilai lebih dibandingkan dengan pesaingnya itulah yang akan diminati oleh konsumen. Akibat dari pemberian nilai yang lebih bagi konsumen atau superior customer value maka akan menimbulkan kepuasan bagi konsumen dan akhirnya menjadi loyal. Kepuasan konsumen menjadi sangat penting bagi aktivitas pemasaran perusahaan yang berorientasi pada pasar (Kandampully dan Suhartanto, 2000). Kepuasan konsumen menyebabkan timbulnya pembelian kembali (Soelasih, 2015) yang berakibat pada sikap 
konsumen sehingga mau menceritakan kepada orang lain akan produk atau jasa yang digunakan mereka. Ada hubungan positif antara kepuasan konsumen dengan loyalitas konsumen (Kandampully et.al., 2000). Bila pembelian terjadi terus menerus maka menyebabkan konsumen menjadi loyal terhadap jasa perkeretaapian. Konsumen loyal adalah konsumen yang melakukan pembelian kembali dari pemberi jasa yang sama dan secara kontinyu merekomendasikan atau mempunyai sikap positif terhadap pemberi jasa (Kandampully et.al., 2000). Tingkat kepuasan mempunyai pengaruh terhadap loyalitas konsumen (Dimyati, 2015; Shoki et.al., 2012; Deng et.al.,2010: Yang et.al., 2004).

H3: Terjadi pengaruh antara kepuasan konsumen (customer satisfaction) terhadap loyalitas konsumen (customer loyalty).

Komitmen konsumen yang diukur dari affective dan calculative mempunyai pengaruh terhadap sikap loyalitas konsumen (Kaur et al., 2013). Komitmen konsumen sebagai variabel mediasi mempunyai pengaruh positif terhadap loyalitas (Tu; Liu; Chang, 2014). Komitmen afektif dan kontinyu mempunyai pengaruh positif terhadap retensi pelanggan (Fullerton, 2003).

H4 : Terjadi pengaruh antara komitmen konsumen(customer commitment) terhadap loyalitas konsumen (customer loyalty).

H5 : Terjadi pengaruh antara customer perceived value terhadap kepuasan konsumen (customer satisfaction) dan komitmen konsumen (customer commitment)

H6 : Terjadi pengaruh antara kepuasan konsumen ( customer satisfaction) dan komitmen konsumen (customer commitment) terhadap loyalitas konsumen (customer loyalty).

Pada kajian teori diatas maka memunculkan model penelitian pada gambar 1.

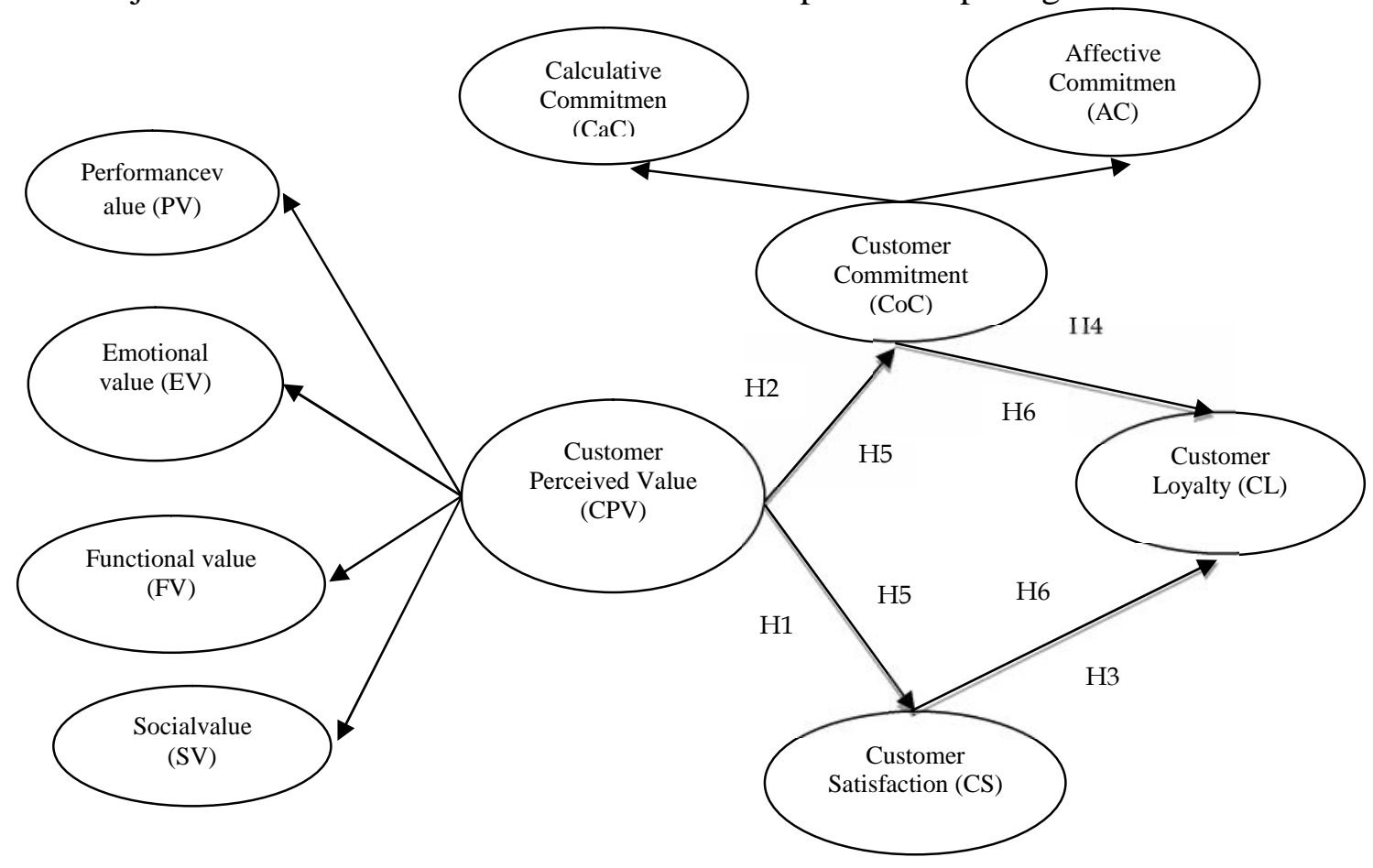

Gambar 1. Model Penelitian 


\section{METODE}

Obyek penelitian ini adalah PT Kereta Api Indonesia khususnya kereta api eksekutif. Unit yang dianalisis adalah penumpang kereta api eksekutif di Pulau Jawa. Untuk populasi dalam penelitian ini tidak diketahui, oleh karena itu minimal sampel yang dapat dianalisis menggunakan SEM adalah 100 sampel, sedangkan penelitian ini menggunakan jumlah sampel sebanyak 323 responden. Pengambilan sampel dengan menggunakan probabilitas dengan cara acak sederhana artinya semua orang mempunyai peluang yang sama untuk terambil. Dalam melakukan pengujian indikator dan variabel maka menggunakan reliabilitas dan validitas. Hasil uji reliabilitas dan validitas menggunakan SPSS yang terlihat pada tabel 3 .

Tabel 3. Uji Reliabilitas dan Validitas

\begin{tabular}{cccc}
\hline No. & Sub variable/variable & $\begin{array}{c}\text { Cronbach's } \\
\text { Alpha }\end{array}$ & $\begin{array}{c}\text { Validity } \\
\text { (signifikan) }\end{array}$ \\
\hline 1 & Performance value & 0.898 & 0.00 \\
2 & Emotional value & 0.804 & 0.00 \\
3 & Functional value & 0.887 & 0.00 \\
4 & Social value & 0.803 & 0.00 \\
5 & Calculative Commitment & 0.743 & 0.00 \\
6 & Affective Commitment & 0.815 & 0.00 \\
7 & Customer satisfaction & 0.863 & 0.00 \\
8 & Customer loyalty & 0.850 & 0.00 \\
\hline
\end{tabular}

Tabel 3 menunjukkan bahwa semua variabel yang digunakan dalam penelitian ini menunjukkan reliabel, dengan nilai diatas 0.7. Dalam bukunya Uyanto, (2009: 274) menunjukkan bahwa skala pengukuran yang reliabel sebaiknya memiliki nilai alpha cronbach minimal 0.70. Artinya hasil uji reliabilitas pada Tabel 3 memenuhi syarat untuk digunakan didalam penelitian ini. Untuk nilai validitasnya diatas menunjukkan hasil uji validitas dengan menggunakan correlation, hasil uji validitas menunjukkan bahwa nilai setiap indikator ke sub variabel maupun variabel diatas signifikan berarti nilai validitas memenuhi syarat.

Setelah dilakukan uji instrumen baik ke sub variabel maupun ke variabel maka langkah berikutnya dilakukan uji model. Pada penelitian ini untuk uji model menggunakan structural equation modelling dengan LISREL 8.8. Hasil uji model seperti terlihat pada Tabel 4.

Tabel 4. Hasil uji model

\begin{tabular}{lccc}
\hline \multicolumn{1}{c}{ Fit Measure } & Good Fit & Acceptable Fit & Estimated \\
\hline$\chi^{2} / \mathrm{df}$ & $0 \leq \chi^{2} / d f \leq 2$ & $2<\chi^{2} / d f \leq 3$ & 3.24 \\
$R M S E A$ & $0 \leq \mathrm{RMSEA} \leq 0.05$ & $0.05 \leq \mathrm{RMSEA} \leq 0.08$ & 0.08 \\
SRMR & $0 \leq \mathrm{SRMR} \leq 0.05$ & $0.05 \leq \mathrm{SRMR} \leq 0.10$ & 0.09 \\
$N F I$ & $0.95 \leq \mathrm{NFI} \leq 100$ & $0.90 \leq \mathrm{NFI} \leq 0.95$ & 0.93 \\
$N N F I$ & $0.97 \leq \mathrm{NNFI} \leq 100$ & $0.95 \leq \mathrm{NNFI} \leq 0.97$ & 0.95 \\
$C F I$ & $0.97 \leq \mathrm{CFI} \leq 100$ & $0.95 \leq \mathrm{CFI} \leq 0.97$ & 0.95 \\
\hline
\end{tabular}

Sumber: Engel; Moosbrugger; Muller (2003). Evaluating the Fit of Structural Equation Models: Tests of Significance and Descriptive Goodness-of-Fit Measures and estimated 
Tabel 4 menunjukkan bahwa hasil uji model penelitian secara keseluruhan dapat diterima, walaupun ada nilai yang masuk dalam kategori cukup. Untuk nilai RMSEA,SRMR, NFI, NNFI,dan CFI menunjukkan bahwa model tersebut dapat digunakan dalam penelitian ini walaupun nilainya acceptable fit.

\section{HASIL DAN PEMBAHASAN}

Data yang terkumpul diolah menggunakan SPSS untuk melihat kareakteristik dan tabel frekuensinya sedangkan untuk uji hipotesisi maka menggunakan structural equation modelling. Untuk karakteristik rersponden dari data 323 sebagai berikut:

Tabel 5. Karakteristik Responden

\begin{tabular}{lrr}
\hline \multicolumn{1}{c}{ Keterangan } & Jumlah & Persentase (\%) \\
\hline Jenis kelamin: & & \\
Pria & 162 & 50.2 \\
Wanita & 161 & 49.2 \\
Usia: & & \\
17 - 21tahun & 40 & 12.4 \\
22 - 26tahun & 98 & 30.3 \\
27 - 31tahun & 67 & 20.7 \\
32 - 36tahun & 46 & 14.2 \\
37 - 40tahun & 24 & 7.4 \\
>40 tahun & 48 & 14.9 \\
Pendidikan: & & \\
SMA & 42 & 13.0 \\
DIPLOMA & 76 & 23.5 \\
S1 & 149 & 46.1 \\
S2 & 27 & 8.4 \\
S3 & 12 & 3.7 \\
LAINNYA & 17 & 5.3 \\
Pekerjaan: & & 12.7 \\
Mahasiswa & 41 & 22.3 \\
Pegawai Negeri & 72 & 35.0 \\
Pegawai Swasta & 113 & 12.1 \\
Wirausaha & 39 & 18.0 \\
lainnya & 58 & \\
\hline \multicolumn{1}{l}{ n = 323 } & &
\end{tabular}

Tabel 5 menunjukkan bahwa responden yang terambil seimbang antara pria dan wanita, hal ini menunjukkan bahwa baik pria maupun wanita senang bepergian dengan menggunakan kereta api eksekutif. Usia responden yang terbanyak pada range antara 22 - 26 tahun, menunjukkan bahwa pada usia tersebut mereka minimal sudah lulus S1 hal ini dibuktikan dengan tingkat pendidikan terbanyak pada jenjang S1. Artinya mereka sudah lulus S1 dan sudah bekerja. Pada saat mereka bepergian cenderung menggunakan kereta api eksekutif. Rata-rata responden yang terambil adalah pegawai swasta terbanyak dan yang kedua pegawai negeri. Kemungkinan mereka dalam perjalanan dinasnya menggunakan kereta api eksekutif. 
Untuk membahas pada permasalahan yang diteliti maka menggunakan uji hipotesis dengan structural equation modelling yang terlihat pada Tabel 6.

Tabel 6. Hasil uji hipotesis

\begin{tabular}{|c|c|c|c|c|c|c|}
\hline No. & Hipotesis & $\begin{array}{l}\text { Koefisien } \\
\text { Jalur }\end{array}$ & $\begin{array}{l}\text { Nilai - } \\
\mathrm{t}\end{array}$ & t-tabel & Hasil & Kesimpulan \\
\hline H1. & $\begin{array}{l}\text { Pengaruh customer } \\
\text { perceived valuet } \\
\text { erhadap customer } \\
\text { satisfaction }\end{array}$ & 0.84 & 14.30 & 1.96 & signifikan & $\begin{array}{l}\mathrm{H}_{0} \text { ditolak, terjadi } \\
\text { pengaruh antara } \\
\text { customer perceived } \\
\text { value terhadap } \\
\text { customer } \\
\text { satisfaction }\end{array}$ \\
\hline $\mathrm{H} 2$. & $\begin{array}{l}\text { Pengaruh customer } \\
\text { perceived value } \\
\text { terhadap customer } \\
\text { commitment }\end{array}$ & 0.34 & 4.58 & 1.96 & signifikan & $\begin{array}{l}\mathrm{H}_{0} \text { ditolak, terjadi } \\
\text { pengaruh antara } \\
\text { customer perceived } \\
\text { value terhadap } \\
\text { customer } \\
\text { commitment }\end{array}$ \\
\hline H3. & $\begin{array}{l}\text { Pengaruh customer } \\
\text { satisfaction terhadap } \\
\text { customer loyalty }\end{array}$ & 0.06 & 1.03 & 1.96 & $\begin{array}{l}\text { Tidak } \\
\text { signifikan }\end{array}$ & $\begin{array}{l}\mathrm{H}_{0} \text { diterima, tidak } \\
\text { terjadi pengaruh } \\
\text { antara customer } \\
\text { satisfaction } \\
\text { terhadap customer } \\
\text { loyalty }\end{array}$ \\
\hline H4. & $\begin{array}{l}\text { Pengaruh customer } \\
\text { commitment terhadap } \\
\text { customer loyalty }\end{array}$ & 0.87 & 11.00 & 1.96 & signifikan & $\begin{array}{l}\mathrm{H}_{0} \text { ditolak, terjadi } \\
\text { pengaruh antara } \\
\text { customer } \\
\text { commitment } \\
\text { terhadap customer } \\
\text { loyalty }\end{array}$ \\
\hline
\end{tabular}

Hipotesis 1 menunjukkan terjadinya pengaruh antara nilai yang diterima konsumen (customer perceived value) terhadap kepuasan konsumen (customer satisfaction), hal ini menunjukkan bahwa pelayanan yang diberikan oleh PT Kereta Api Indonesia khususnya kereta api eksekutif sangat mempengaruhi kepuasan penumpang. Oleh sebab itu pelayanan menjadi utama bagi jasa kereta api eksekutif. Dalam mengukur nilai yang diterima konsumen maka menggunakan empat dimensi yaitu performance value, emotional value, functional value dan social value. Hasil ini didukung dengan tabel frekuensi pada nilai yang diterima konsumsi kereta api eksekutif pada Tabel 7 sampai dengan 10.

Tabel 7. Hasil frekuensi performance value

\begin{tabular}{|c|c|c|c|c|c|c|}
\hline Keterangan & $\begin{array}{l}\text { Sangat } \\
\text { Tidak } \\
\text { Setuju }\end{array}$ & $\begin{array}{l}\text { Tidak } \\
\text { Setuju }\end{array}$ & $\begin{array}{l}\text { Kurang } \\
\text { Setuju }\end{array}$ & $\begin{array}{l}\text { Cukup } \\
\text { Setuju }\end{array}$ & Setuju & $\begin{array}{l}\text { Sangat } \\
\text { Setuju }\end{array}$ \\
\hline Standar kualitas pelayanan & 3 & 2 & 8 & 73 & 183 & 54 \\
\hline Kualitas pelayanan konsisten & 4 & 2 & 23 & 75 & 168 & 51 \\
\hline $\begin{array}{l}\text { Pelayanan terkoordinasi } \\
\text { dengan baik }\end{array}$ & 2 & 2 & 17 & 76 & 175 & 51 \\
\hline
\end{tabular}


Tabel 7 menunjukkan tentang performance value yang diberikan oleh kereta api eksekutif, terlihat rata-rata konsumen menjawab pada setuju terhadap pernyataan tersebut, artinya konsumen merasa performance value yang diterima sudah sesuai dengan apa yang diharapkan oleh penumpang.

Tabel 8. Hasil frekuensi emotional value

\begin{tabular}{lcccccc}
\hline Keterangan & $\begin{array}{l}\text { Sangat Tidak } \\
\text { Setuju }\end{array}$ & $\begin{array}{l}\text { Tidak } \\
\text { Setuju }\end{array}$ & $\begin{array}{c}\text { Kurang } \\
\text { Setuju }\end{array}$ & $\begin{array}{c}\text { Cukup } \\
\text { Setuju }\end{array}$ & Setuju & $\begin{array}{c}\text { Sangat } \\
\text { Setuju }\end{array}$ \\
\hline $\begin{array}{l}\text { Kereta api kelas } \\
\text { eksekutif memberikan }\end{array}$ & 3 & 2 & 15 & 88 & 156 & 59 \\
$\begin{array}{l}\text { kepuasan } \\
\begin{array}{l}\text { Kereta api kelas } \\
\text { eksekutif memberikan }\end{array}\end{array}$ & 2 & 6 & 9 & 94 & 146 & 66 \\
$\begin{array}{l}\text { kesenangan } \\
\begin{array}{l}\text { Selalu menggunakan } \\
\text { kereta api kelas eksekutif }\end{array}\end{array}$ & 4 & 2 & 28 & 99 & 133 & 57 \\
\hline
\end{tabular}

Tabel 8 menunjukkan bahwa terjadi emotional value bagi pengguna kereta api, terlihat pada jawaban yang lebih banyak pada cukup setuju dan setuju artinya bahwa menimbulkan nilai emosional bagi pengguna kereta api eksekutif.

Tabel 9. Hasil frekuensi functional value

\begin{tabular}{lcccccc}
\hline Keterangan & $\begin{array}{l}\text { Sangat } \\
\text { Tidak } \\
\text { Setuju }\end{array}$ & $\begin{array}{l}\text { Tidak } \\
\text { Setuju }\end{array}$ & $\begin{array}{l}\text { Kurang } \\
\text { Setuju }\end{array}$ & $\begin{array}{l}\text { Cukup } \\
\text { Setuju }\end{array}$ & Setuju & $\begin{array}{l}\text { Sangat } \\
\text { Setuju }\end{array}$ \\
\hline $\begin{array}{l}\text { Harga yang ditawarkan kereta api } \\
\text { kelas eksekutif masuk akal }\end{array}$ & 3 & 6 & 34 & 103 & 141 & 36 \\
$\begin{array}{l}\text { Pelayanan Kereta api kelas } \\
\text { eksekutif sesuai dengan harga }\end{array}$ & 6 & 5 & 38 & 105 & 133 & 36 \\
$\begin{array}{l}\text { Harga Kereta api kelas eksekutif } \\
\text { meningkatkan kepuasaan }\end{array}$ & 3 & 5 & 43 & 111 & 118 & 43 \\
\hline
\end{tabular}

Tabel 9 menunjukkan bahwa functional value yang diterima oleh konsumen sesuai dengan manfaat yang diberikan oleh PT KAI pada kereta api eksekutif, terlihat jawaban responden banyak pada penilaian cukup setuju dan setuju.

Tabel 10. Hasil frekuensi social value

\begin{tabular}{lcccccc}
\hline Keterangan & $\begin{array}{l}\text { Sangat } \\
\text { Tidak } \\
\text { Setuju }\end{array}$ & $\begin{array}{l}\text { Tidak } \\
\text { Setuju }\end{array}$ & $\begin{array}{l}\text { Kurang } \\
\text { Setuju }\end{array}$ & $\begin{array}{l}\text { Cukup } \\
\text { Setuju }\end{array}$ & Setuju & $\begin{array}{l}\text { Sangat } \\
\text { Setuju }\end{array}$ \\
\hline $\begin{array}{l}\text { Penggunaan kereta api kelas } \\
\text { eksekutif memberikan kesan }\end{array}$ & 3 & 3 & 14 & 83 & 170 & 50 \\
$\begin{array}{l}\text { yang baik kepada orang lain } \\
\begin{array}{l}\text { Penggunaan kereta api kelas } \\
\text { eksekutif meningkatkan cara }\end{array}\end{array}$ & 4 & 17 & 69 & 90 & 107 & 36 \\
$\begin{array}{l}\text { pandang orang lain } \\
\begin{array}{l}\text { Penggunaan kereta api kelas } \\
\text { eksekutif memberikan } \\
\text { pengakuan sosial }\end{array}\end{array}$ & 11 & 29 & 69 & 93 & 89 & 32 \\
\hline
\end{tabular}

Jurnal Manajemen/Volume XXI, No. 03, Oktober 2017: 363-380 
Tabel 10 menunjukkan bahwa nilai sosial terjadi pada responden pengguna kereta api eksekutif, terlihat dari jawaban mereka pada range cukup setuju dan setuju yang paling banyak pada pernyataan 1 dan 2 sedangkan untuk pernyataan 3 jawaban cukup setuju yang paling banyak, tetapi bila dibuat dua kutub negative dan positif, maka jawaban responden cenderung pada kutub positif, artinya bahwa nilai sosial mendukung terhadap nilai yang diterima konsumen secara umum.

Hal inilah yang menyebabkan terjadinya pengaruh antara customer perceived value terhadap customer satisfaction. Hasil hipotesis ini mendukung penelitian Parasuraman dan Grewal (2000); Bolton dan Lemon; (1999) dan Chang dan Wildt (1994). Shoki; Fen; Zakuan; Ishak; Ismail, (2012) serta Raji dan Zainal, (2016).

Hasil uji $\mathrm{H} 2$ menunjukkan bahwa terjadi pengaruh antara customer perceived value terhadap customer commitment, artinya dari kualitas pelayanan yang diberikan oleh kereta api eksekutif mempunyai pengaruh terhadap komitmen konsumen, sehingga mereka akan mempunyai komitmen dalam penggunaan kereta api eksekutif secara kontinyu. Untuk mengukur komitmen konsumen maka menggunakan dua dimensi yaitu calculative dan affective. Hasil uji hipotesis 2 juga didukung dengan hasil frekuensi pada Tabel 11 dan 12 dibawah ini.

Tabel 11. Hasil frekuensi calculative commitment

\begin{tabular}{lcccccc}
\hline Keterangan & $\begin{array}{l}\text { Sangat } \\
\text { Tidak } \\
\text { Setuju }\end{array}$ & $\begin{array}{c}\text { Tidak } \\
\text { Setuju }\end{array}$ & $\begin{array}{l}\text { Kurang } \\
\text { Setuju }\end{array}$ & $\begin{array}{c}\text { Cukup } \\
\text { Setuju }\end{array}$ & Setuju & $\begin{array}{l}\text { Sangat } \\
\text { Setuju }\end{array}$ \\
\hline $\begin{array}{l}\text { Hubungan jangka panjang } \\
\text { dengan kereta api kelas } \\
\text { eksekutif }\end{array}$ & 2 & 18 & 40 & 107 & 115 & 41 \\
$\begin{array}{l}\text { Peduli dengan perkembangan } \\
\text { yang dicapai kereta api } \\
\text { eksekutif }\end{array}$ & 3 & 7 & 10 & 72 & 156 & 75 \\
$\begin{array}{l}\text { Peduli dengan kesuksesan yang } \\
\text { dicapai kereta api eksekutif }\end{array}$ & 3 & 3 & 10 & 70 & 166 & 71 \\
$\begin{array}{l}\text { Bangga menggunakan kereta api } \\
\text { kelas eksekutif }\end{array}$ & 3 & 5 & 13 & 81 & 138 & 83 \\
$\begin{array}{l}\text { Selalu menggunakan kereta api } \\
\text { eksekutif selama menawarkan } \\
\text { pelayanan terbaik }\end{array}$ & 3 & 4 & 10 & 64 & 146 & 96 \\
\hline
\end{tabular}

Tabel 11 menunjukkan rata-rata jawaban responden untuk calculative commitment pada range setuju, hal ini menunjukkan bahwa timbul komitmen konsumen pada dimensi calculative, artinya mereka akan secara kontinyu menggunakan kereta api eksekutif.

Tabel 12 berikut menunjukkan bahwa jawaban affective commitment untuk indikator 2,3, dan 4 menunjukkan banyak pada range cukup setuju dan setuju kecuali indikator 1 yang terlihat jawaban cukup setuju yang terbanyak. Tetapi bila dibuat dua kutub antara positif dan negative maka jawaban positif lebih banyak, artinya menunjukkan bahwa komitmen afektif mendukung pada komitmen konsumen.

Hal inilah menjadikan $\mathrm{H} 2$ terbukti bahwa terjadi pengaruh antara nilai yang diterima konsumen terhadap komitmen. Hasil penelitian ini mendukung penelitian yang dilakukan oleh Mosavi dan Ghaedi, (2012). 
Tabel 12. Hasil frekuensi affective commitment

\begin{tabular}{|c|c|c|c|c|c|c|}
\hline Keterangan & $\begin{array}{l}\text { Sangat } \\
\text { Tidak } \\
\text { Setuju }\end{array}$ & $\begin{array}{l}\text { Tidak } \\
\text { Setuju }\end{array}$ & $\begin{array}{l}\text { Kurang } \\
\text { Setuju }\end{array}$ & $\begin{array}{l}\text { Cukup } \\
\text { Setuju }\end{array}$ & Setuju & $\begin{array}{l}\text { Sangat } \\
\text { Setuju }\end{array}$ \\
\hline $\begin{array}{l}\text { Terikat secara emosional } \\
\text { terhadap kereta api kelas } \\
\text { eksekutif }\end{array}$ & 6 & 28 & 57 & 120 & 79 & 33 \\
\hline $\begin{array}{l}\text { Komitmen dengan kereta api } \\
\text { kelas eksekutif }\end{array}$ & 2 & 19 & 56 & 112 & 112 & 22 \\
\hline $\begin{array}{l}\text { Menggunakan kereta api } \\
\text { eksekutif, meskipun tidak } \\
\text { promosi }\end{array}$ & 1 & 5 & 39 & 93 & 148 & 37 \\
\hline $\begin{array}{l}\text { Tetap menjadi pelanggan } \\
\text { dari kereta api eksekutif }\end{array}$ & 2 & 8 & 35 & 110 & 130 & 38 \\
\hline
\end{tabular}

Hipotesis 3 menunjukkan bahwa customer satisfaction tidak mempunyai pengaruh terhadap customer loyalty. Hal ini ditunjukkan dengan nilai t-value sebesar 1,03 sedangkan nilai t-tabel sebesar 1,96, artinya bahwa kepuasan konsumen untuk pengguna kereta api eksekutif tidak mempunyai pengaruh terhadap loyalitas konsumen. Oleh karena itu pihak PT KAI dapat membuat suatu program untuk dapat meningkatkan loyalitas konsumennya seperti frequent flyer yang dimiliki oleh PT Garuda Indonesia. Pada saat konsumen mempunyai kartu keanggotaan pada kereta api khususnya eksekutif, maka hal ini akan dapat meningkatkan komitmen mereka dalam menggunakan kereta api tersebut. Kartu keanggotaan yang mempunyai manfaat bagi konsumen didalam menggunakan kereta api eksekutif tersebut, sehingga mempunyai dampak terhadap kenaikan penumpang kereta api eksekutif. Oleh karena itu pihak PT KAI dapat membuat suatu program yang dapat meningkatkan komitmen bagi konsumen. Hasil H3 bertolak belakang dengan hasil penelitian Kandampully dan Suhartanto (2000), Dimyati, (2015), Shoki et.al., (2012), Deng et.al., (2010) dan Yang et.al., (2004). Menurut hasil penelitian mereka menyatakan bahwa bila konsumen puas maka akan menimbulkan loyalitas. Tetapi hasil penelitian Kumar et.al.,2013 menunjukkan bahwa kepuasan tidak cukup untuk membentuk loyalitas konsumen. Sehingga hasil penelitian ini mendukung penelitian yang dilakukan oleh Kumar et.al., 2013. Untuk itu pada kereta api eksekutif, menunjukkan bahwa walaupun mereka puas, tidak membuat loyal. Transportasi di Indonesia beraneka ragam, sehingga tingkat persaingan menjadi tinggi dan tingkat untuk memilih penggunaan transportasi bagi konsumen juga banyak, karena itu hampir tidak menimbulkan loyalitas bagi mereka. Konsumen dapat membandingkan tarif transportasi yang ada, terlihat bahwa tarif penerbangan yang low cost carrier dengan tarif kereta api eksekutif relative sama. Oleh karena itu konsumen mempunyai pilihan dapat menggunakan kereta api atau pesawat dalam perjalanan menuju daerah lain di Pulau Jawa. Disisi lain dengan kondisi jalan yang baik maka mereka juga punya alternative bepergian dengan menggunakan kendaraan pribadi. Masalah inilah yang menyebabkan walaupun mereka puas tetapi tidak loyal terhadap kereta api eksekutif. 
Tabel 13. Hasil frekuensi customer satisfaction

\begin{tabular}{|c|c|c|c|c|c|c|}
\hline Keterangan & $\begin{array}{l}\text { Sangat } \\
\text { Tidak } \\
\text { Setuju }\end{array}$ & $\begin{array}{l}\text { Tidak } \\
\text { Setuju }\end{array}$ & $\begin{array}{l}\text { Kurang } \\
\text { Setuju }\end{array}$ & $\begin{array}{l}\text { Cukup } \\
\text { Setuju }\end{array}$ & Setuju & $\begin{array}{l}\text { Sangat } \\
\text { Setuju }\end{array}$ \\
\hline $\begin{array}{l}\text { Kereta api kelas } \\
\text { eksekutif yang } \\
\text { ditawarkan memenuhi } \\
\text { harapan }\end{array}$ & 3 & 8 & 23 & 108 & 146 & 35 \\
\hline $\begin{array}{l}\text { Pilihan menggunakan } \\
\text { kereta api kelas eksekutif } \\
\text { adalah salah satu pilihan } \\
\text { yang bijaksana }\end{array}$ & 3 & 3 & 24 & 103 & 147 & 43 \\
\hline $\begin{array}{l}\text { Secara keseluruhan puas } \\
\text { dengan fasilitas yang } \\
\text { didapatkan dari kereta } \\
\text { api kelas eksekutif }\end{array}$ & 2 & 5 & 20 & 101 & 138 & 57 \\
\hline
\end{tabular}

Tabel 13 menunjukkan bahwa responden rata-rata cukup setuju dan setuju pada indikator kepuasan tersebut. Sesuai teori di dalam pemasaran, dimana konsumen puas maka akan menimbulkan loyalitas. Hasil penelitian ini menunjukkan bahwa responden puas tetapi tidak loyal, maka hasil ini tidak mendukung penelitian yang dilakukan oleh Yang et.al.,, (2004). Hasil penelitian Yang, et.al., (2004), menunjukkan bahwa kepuasan konsumen menyebabkan konsumen akan loyal begitu juga penelitian yang dilakukan oleh Dimyati (2015).

Tabel 14. Hasil frekuensi customer loyalty

\begin{tabular}{|c|c|c|c|c|c|c|}
\hline Keterangan & $\begin{array}{l}\text { Sangat } \\
\text { Tidak } \\
\text { Setuju }\end{array}$ & $\begin{array}{l}\text { Tidak } \\
\text { Setuju }\end{array}$ & $\begin{array}{l}\text { Kurang } \\
\text { Setuju }\end{array}$ & $\begin{array}{l}\text { Cukup } \\
\text { Setuju }\end{array}$ & Setuju & $\begin{array}{l}\text { Sangat } \\
\text { Setuju }\end{array}$ \\
\hline $\begin{array}{l}\text { Mengatakan hal-hal } \\
\text { positif mengenai kereta } \\
\text { api kelas ekskutif, }\end{array}$ & 2 & 5 & 15 & 87 & 166 & 48 \\
\hline $\begin{array}{l}\text { Mendorong teman-teman } \\
\text { atau kerabat untuk } \\
\text { menggunakan kereta api } \\
\text { kelas ekskutif }\end{array}$ & 3 & 11 & 35 & 99 & 126 & 49 \\
\hline $\begin{array}{l}\text { Merekomendasikan } \\
\text { kereta api kelas ekskutif, }\end{array}$ & 4 & 11 & 40 & 74 & 142 & 52 \\
\hline
\end{tabular}

Tabel 14 menunjukkan bahwa responden cenderung loyal didalam penggunaan kereta api eksekutif, terlihat pada jawaban yang banyak pada range cukup setuju dan setuju. Hasil uji Hipotesis 4 menunjukkan bahwa bila konsumen komitmen terhadap jasa kereta api eksekutif maka terjadi loyalitas. Komitmen yang timbul pada diri konsumen akan menimbulkan penggunaan kembali pada transportasi yang sama, sehingga akan meningkatkan loyalitas mereka. Hasil penelitian ini mendukung penelitian yang dilakukan oleh Kaur et al., (2013); Tu et al., (2014) dan Fullerton (2003). 
Untuk H5 dan H6 terlihat pada gambar 2 dibawah. Hasil uji H5 ditunjukkan pada persamaan sebagai berikut:

Kepuasan Konsumen $=0.94 \mathrm{CPV}$

Komitmen Konsumen $=0.27 \mathrm{CPV}$

Pada persamaan diatas terlihat pengaruh antara nilai yang diterima konsumen terhadap kepuasan konsumen maupun komitmen konsumen. Pengaruh terbesar dari nilai yang diterima oleh konsumen pada kepuasan yang ditimbulkan dibandingkan komitmen yang ada.

Hasil uji $\mathrm{H6}$ terlihat pada persamaan dibawah ini.

$$
\mathrm{CL}=-0.01 \mathrm{CS}+0.89 \mathrm{CC}
$$

Persamaan tersebut menunjukkan bahwa kepuasan konsumen tidak membentuk pada loyalitas, hal ini disebabkan karena transportasi yang digunakan oleh konsumen banyak pilihannya. Tetapi bila konsumen timbul komitmen maka menimbulkan loyalitas. Karena itu komitmen konsumen dalam penggunaan kereta api eksekutif harus dimunculkan supaya loyalitas timbul, karena pengaruhnya sangat tinggi dilihat dari persamaan diatas.

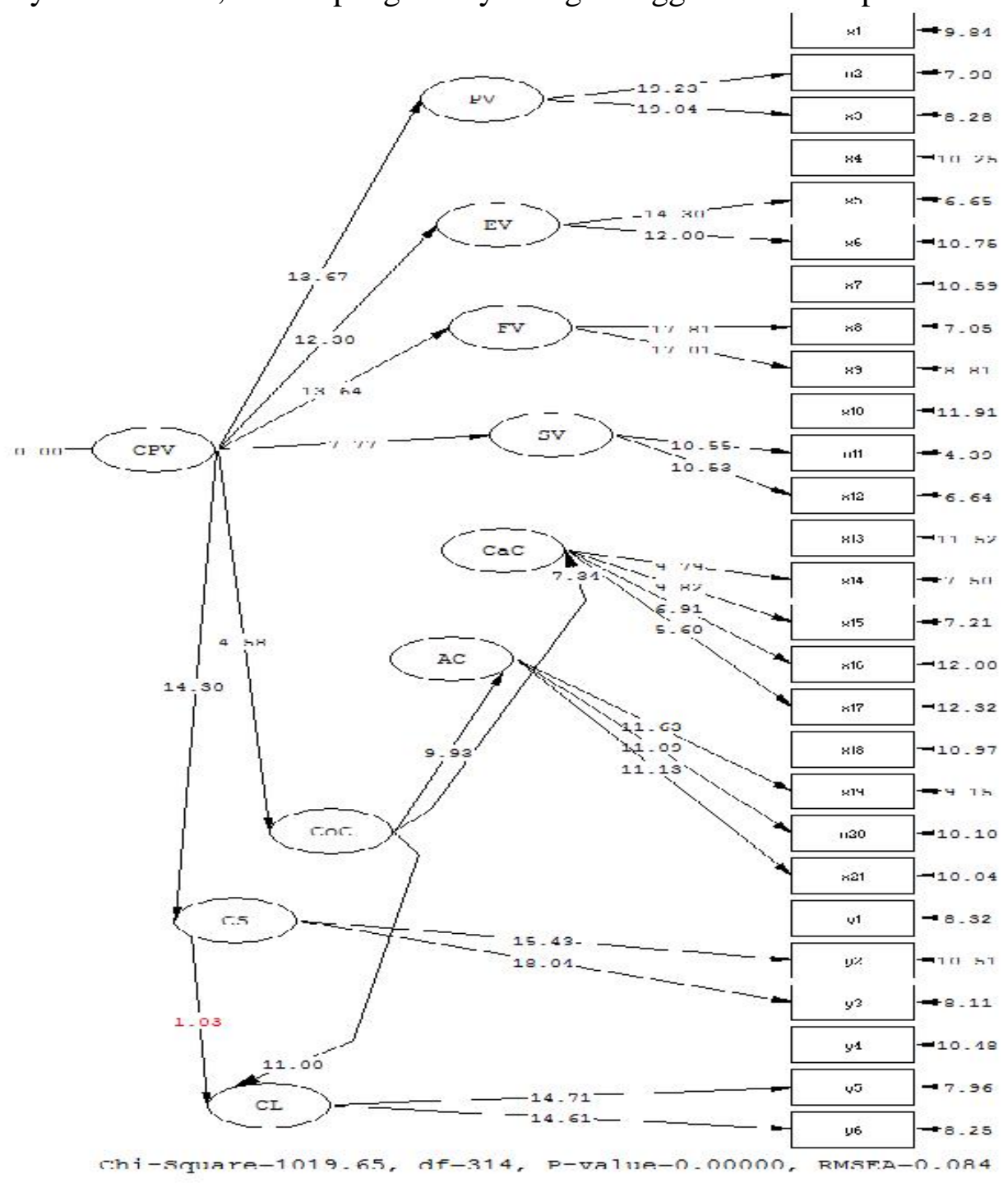

Gambar 2. Hasil output lisrel 
Pada persamaan secara keseluruhan menunjukkan bahwa nilai yang diterima konsumen tidak terlalu besar pengaruhnya terhadap komitmen sedangkan yang membentuk loyalitas adalah komitmen. Oleh karena itu perusahaan PT KAI harus mempertimbangkan faktor yang lain untuk membentuk komitmen penumpang kereta api khususnya eksekutif.

Pada gambar 2 diatas menunjukkan olahan dengan SEM menghasilkan dimensi pada nilai yang diterima konsumen mempunyai nilai t diatas 1,97 artinya bahwa semua dimensi dapat membentuk variabel tersebut. Pengaruh antar variabel juga mempunyai nilai t yang signifikan khususnya pada nilai yang diterima konsumen terhadap kepuasan konsumen dan komitmen konsumen serta komitmen konsumen terhadap loyalitas konsumen kecuali pengaruh kepuasan konsumen terhadap loyalitas yang tidak mempunyai pengaruh.

Hasil penelitian ini berbeda dengan hasil yang dilakukan oleh peneliti-peneliti sebelumnya. Penelitian yang dilakukan oleh Dimyati, 2015; Shoki et.al., 2012; Deng et.al.,2010: Yang et.al., 2004 menunjukkan bahwa konsumen puas terhadap produk atau jasa maka mereka akan loyal, tetapi untuk penelitian ini menghasilkan bahwa konsumen puas tetapi mereka kurang loyal terhadap kereta api eksekutif. Tetapi hasil penelitian ini mendukung penelitian Kumar et.al.,2013 yang menunjukkan bahwa kepuasan tidak cukup untuk membentuk loyalitas konsumen. Dalam bukunya Kotler dan Keller (2016: 282) bahwa tingkat loyalitas konsumen dibedakan menjadi empat yaitu: hard-core loyals, split loyals, shifting loyals dan switchers. Hard-core loyals dimana konsumen hanya membeli suatu produk dan atau jasa pada satu merek dan tidak pernah berpindah pada merek yang lain. Split loyals, dimana konsumen akan menggunakan dua atau tiga merek untuk produk atau jasa yang sama. Shifting loyals, dimana konsumen sering berpindah dari satu merek ke merek lain untuk produk atau jasa yang dikonsumsi. Switchers, dimana konsumen tidak loyal terhadap merek untuk produk dan atau jasa yang dikonsumsi. Bila dilihat pada tabel14 menunjukkan bahwa mereka puas tetapi kemungkinan kepuasan mereka tidak terlalu menyebabkan loyalitas, karena konsumen ini mungkin termasuk dalam kategori shifting loyals, artinya mereka dapat menggunakan berbagai macam transportasi seperti penerbangan, kereta api maupun kendaraan dalam bepergian tergantung dari kebutuhan mereka di Pulau Jawa. Tetapi bila konsumen sudah mempunyai komitmen terhadap kereta api maka akan menimbulkan loyalitas. Oleh karena itu yang perlu dibangun selain kepuasan adalah komitmen yang terjadi pada diri konsumen. Hasil penelitian ini menunjukkan bahwa komitmen konsumen dalam penggunaan produk atau jasa dapat meningkatkan loyalitas mereka. Diharapkan pengguna kereta api dalam meningkatkan loyalitasnya seperti dalam bukunya Kotler et.al.(2016: 282) minimal ke split loyalty maka dibangunlah komitmen pada diri konsumen selain faktor kepuasan mereka.

\section{PENUTUP}

Simpulan. Penelitian ini menghasilkan pertentangan teori untuk kepuasan. Dalam banyak penelitian tentang kepuasan yang dihubungkan dengan loyalitas, terlihat hasil bahwa kepuasan mempunyai pengaruh terhadap loyalitas. Tetapi dalam penelitian ini variabel kepuasan tidak membentuk loyalitas. Hal ini disebabkan karena transportasi yang dapat digunakan di Indonesia berbagai macam, seperti penerbangan, kendaraan umum, kendaraan pribadi maupun kapal laut. Oleh karena itu pilihan konsumen menjadi 
banyak dalam menggunakan transportasi. Sehingga menyebabkan tingkat loyalitas konsumen terhadap satu transportasi menjadi relatif rendah. Untuk meningkatkan loyalitas pada kereta api eksekutif maka pihak PT KAI dapat membuat kartu keanggotaan bagi penggunanya seperti frequent flyer PT Garuda Indonesia. Karena kartu keanggotaan akan menimbulkan komitmen bagi mereka dalam menggunakan kereta api eksekutif. Maka konsumen yang tingkat kepuasannya sudah terbentuk akan menjadi komitmen dalam menggunakan kereta api eksekutif sehingga menimbulkan loyalitas. Karena pada saat ini PT KAI belum mempunyai kartu keanggotaan penumpang, maka walaupun konsumen puas tetapi mereka tidak loyal terhadap PT KAI, hal ini disebabkan pilihan transportasi di Inonesia banyak ragamnya. Untuk variabel lain yang diteliti menunjukkan bahwa nilai yang diterima konsumen mempunyai pengaruh terhadap kepuasan konsumen dan komitmen konsumen baik secara parsial maupun simultan. Sedangkan untuk kepuasan dan komitmen terhadap loyalitas menunjukkan bahwa komitmen mempunyai pengaruh terhadap loyalitas sedangkan kepuasan tidak.

Saran. PT Ketera Api Indonesia terutama kereta api eksekutif tetap memperhatikan kualitas pelayanan yang diberikan kepada konsumen. Kualitas pelayanan ini akan menjadi dasar pada komitmen dan kepuasan konsumen, sehingga pada saat membutuhkan transportasi maka kereta api eksekutif dapat menjadi salah satu pilihan dalam melakukan perjalanan mereka. Oleh karena itu PT KAI dapat mengeluarkan kartu keanggotaan bagi penumpang kereta api eksekutif. Kartu tersebut yang mempunyai nilai lebih bagi konsumen sehingga mereka akan cenderung menggunakan transportasi ini.

Pengembangan penelitian lebih lanjut dengan obyek yang berbeda sehingga terjadi perkembangan ilmu dimana kepuasan konsumen belum tentu membentuk loyalitas konsumen. Bila ini terjadi maka akan memperkuat teori bahwa kepuasan konsumen belum tentu membentuk loyalitas. Ada variabel lain yang memperkuat terbentuknya loyalitas bagi konsumen tersebut. Hal ini perlu dilakukan penelitian lebih lanjut.

\section{DAFTAR RUJUKAN}

Al-Hawari, Mohammad Ahmad. (2011) "Automated service quality as a predictor of customers' commitment: A practical study within the UAE retail banking context". Asia Pacific Journal of Marketing and Logistics. 23 (3), 346 - 366.

Bolton, R.N.,\& Lemon, K.N. (1999) “A dynamic model of customers' usage of services: Usage as an antecedent and consequence of satisfaction". Journal of Marketing Research, 36, 171-186.

Burns, Mary Jane. (1993) Value in Exchange: The Consumer Perspective. Knoxville: The University of Tennessee.

Chang,T. Z., \& Wildt, A. R. (1994) "Price, product information, and purchase intention: An empirical study". Journal of the Academy of Marketing Science, 22, 16-27.

Deng, Zhaohua; Lu, Yaobin; Wei, Kwok Kee; Zhang, Jinlong. (2010) "Understanding customer satisfaction and loyalty: An empiricalstudy of mobile instant messages in China”. International Journal of Information Management, 30, 289 - 300.

Dimyati, Mohamad. (2015) "The Role Of Customer Satisfaction In Mediating Marketing Communication Effect On Customer Loyalty". Researchers Word-Journal of Arts, Science \& Commerce. 4 (1), Oct (75). 
Eakuru, N. \& Mat, N. K. N. (2008) “The application of structural equation modeling (SEM) in determing the antecedents of customer loyalty in banks in South Thailand". The Business Review, Cambridge, 10(2), 129-139.

Engel, Karin Schermelleh; Moosbrugger, Helfried; Muller, Hans. (2003) "Evaluating the Fit of Structural Equation Models: Tests of Significance and Descriptive Goodness-of-Fit Measures". Methods of Psychological Research Online, 8 (2), 23-74.

Forgas-Coll, Santiago; Palau-Saumell, Ramon; Sanchez-Garcia, Javier; Fandos-Roig, Juan Carlos. (2013) Airline website loyalty formation and the moderating effects of gender and education. Serv Bus, 7, 255-274

Fullerton, Gordon. (2003) "When Does Commitment Lead to Loyalty?", Journal of Service Research. 5, 333.

Fullerton, G. (2011) "Creating advocates: the roles of satisfaction, trust and commitment", Journal of Retailing and Consumer Services, 18, 92-100.

Heskett, James L., Thomas O. Jones, Gary W. Loveman, Earl W. Sasser, and Leonard A. Schlesinger. (1994) "Putting the Service-Profit Chain to Work." Harvard Business Review 72 (2), 164-174.

Kandampully, Jay; Suhartanto, Dwi. (2000) "Customer loyalty in the hotel industry: the role of customer satisfaction and image". International Journal of Contemporary Hospitality Management. 12(6), 346-351

Kaur, H. \& Soch, H. (2013) "Mediating roles of commitment and corporate image in the formation of customer loyalty". Journal of Indian Business Research, 5(1), 33-51.

Kotler, Philip; Keller, Lane. (2016) Marketing Management. $15^{\text {th }}$ edition. Pearson Education. Pp. 282.

Kumar,V.; Pozza, Ilaria Dalla; Ganesh, Jaishankar. (2013) "Revisiting the SatisfactionLoyalty Relationship: Empirical Generalizations and Directions for Future Research". Journal of Retailing. 89 (March), 246-262

Lapierre, Jozee. (2000) "Customer-perceived value in industrialcontexts". Journal of Business \& Industrial Marketing, 2 (3), 122 - 140.

Lichtenthal, J.D.; Wilson, D.T. and Long, M.M. (1997) "Scientific contributions to the field from the Journal of Business-to-Business Marketing”. Journal of Business Research, 38, 211-233.

Lim, H., Widdows, R., \& Park, J. (2006) "M-loyalty: Winning strategies for mobile carriers". Journal of Consumer Marketing, 23(4), 208-218.

McMullan, Rosalind; Gilmore, Audrey. (2008) "Customer loyalty: an empirical study". European Journal of Marketing. 42 (9/10), 1084-1094.

Mosavi, Seyed Alireza; Ghaedi, Mahnoosh. (2012) "A survey on the relationship between perceived value and customer advocacy behavior". African Journal of Business Management, 6(4), 1383-1395

Pantouvakis, Angelos; Lymperopoulos, Konstantinos. (2008) "Customer satisfaction and loyalty in the eyes of new and repeat customers: Evidence from the transport sector". Managing Service Quality, 18 (6), 623-643.

Parasuraman, A; Grewal, Dhruv. (2000) "The Impact of Technology on the QualityValue-Loyalty Chain: A Research Agenda". Journal of the Academy of Marketing Science. Volume 28, No. 1, pages 168-174. 
Raji, Mohd Nazri Abdul; Zainal, Artinah. (2016) "The effect of customer perceived value on customer satisfaction: A case study of Malay upscale restaurants". Geografia Online ${ }^{T M}$ Malaysian Journal of Society and Space 12 issue 3 (58-68)

Roig, Juan C.F.; Garcia, Javier S.; Tena, Miguel A.M.; Monzonis, Jaume L. (2006). Customer perceived value in banking services. International Journal of Bank Marketing, 24 (5), 266-283.

Ryu, Kisang; Lee, Hye-Rin; Kim, Woon Gon. (2012) "The influence of the quality of the physical environment, food, and service on restaurant image, customer perceived value, customer satisfaction, and behavioral intentions". International Journal of Contemporary Hospitality Managemen. 24 (2).

Schwandt, T. (2003) Three Epistemological Stances for Qualitative Inquiry. Interpretivism,Hermeneutics and Social Constructionism”. In: Denzin, N. K. and Lincoln, Y. S. (eds.), TheLandscape of Qualitative Research. Theories and Issues, California: Sage Publications, Inc. pp. 292-331.

Shoki, Mohd. Ariff, Bin Md.; Fen, Hiew Sok; Zakuan, Norhayati; Ishak, Nawawi; Ismail, Khalid. (2012) "Relationship Between Customers' Perceived Value, Satisfaction And Loyalty Of Mobile Phone Users". Review of Integrative Business \& Economics Research. Vo 1(1)

Soelasih, Yasintha. (2015) "Is Physical Evidence Still Valid? A Study of Low Cost Carriers in Indonesia". Gadjah Mada International Journal of Business. 17 (3) (September-December), 203-218.

Sweeney; Jillian C.; Soutar, Geoffrey N. (2001) "Consumer perceived value: The development of a multiple item scale". Journal of Retailing 77, $203-220$.

Tung, Feng-Cheng. (2013) "Customer satisfaction, perceived value and customer loyalty: the mobile services industry in China". African Journal of Business Management. 7 (18), 1730-1737

Tu, Yu-Te; Liu, Wan-Chen; Chang, Yu-Yi. (2014) "Customer Commitment as a Mediating Variable between Corporate Brand Image and Customer Loyalty". Journal of Education and Vocational Research. 5 (1), 17-27

Uyanto, Stanislaus S. (2009) Pedoman Analisis Data dengan SPSS. Graha Ilmu, hal. 222, 274.

Vargo, S. and Lusch, R. (2008a) "Service-Dominant Logic: Continuing the Evolution", Journal of the Academy of Marketing Science, 36 (1), 1-10.

Woodruff, Robert B. (1997) "Customer value: The next source for competitive advantage". Academy of Marketing Science. Journal; Spring; 25, 2; ABI/INFORM Completepg. 139.

Yang, Ching-Chow; Chen, Ping-Shun; Chien,Yu-Hui. (2014) "Customer Expertise, Affective Commitment, Customer Participation, And Loyalty In B \& B Service". International Journal of Organizational Innovation. 6 (4), April.

Yang, Zhilin ; Peterson, Robin T. (2004) "Customer Perceived Value, Satisfaction, and Loyalty: The Role of Switching Costs". Psychology \& Marketing, 21(10),799822 (October). Published online in Wiley InterScience (www.interscience.wiley.com)

www.bps.go.id/linkTabel Statis/ diunduh 27 Juni 2016

http://www.bps.go.id/linkTabelStatis/view/id/1417 diunduh 5 October 2016 